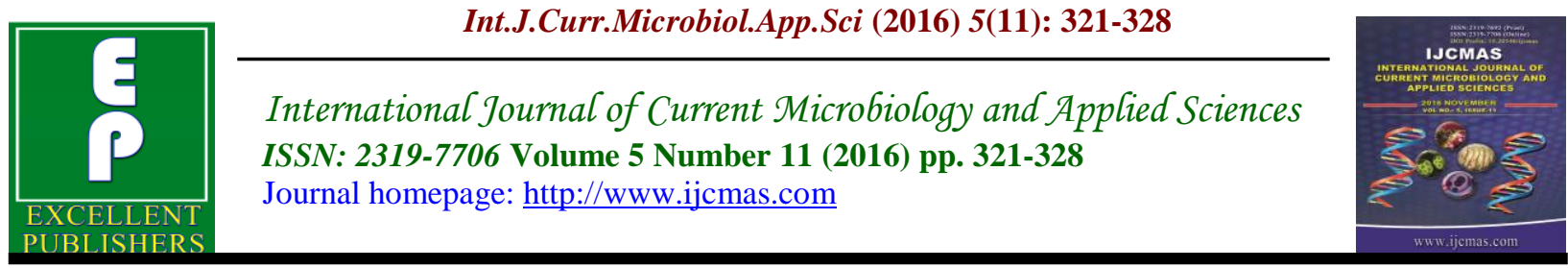

Original Research Article

http://dx.doi.org/10.20546/ijcmas.2016.511.035

\title{
Traditional Healthcare Knowledge of Sedum Taluk, Kalaburgi, Karnataka, South India
}

\author{
Prakash Kariyajjanavar ${ }^{1}$, Sandesh Yargol $^{1}$, K.G. Somashekar Achar ${ }^{2}$ and \\ T.R. Parashurama ${ }^{3} *$ \\ ${ }^{1}$ Department of P.G. Studies and Research in Environmental Science, \\ Gulbarga University, Kalaburagi, India \\ ${ }^{2}$ Panchavati Research Academy for Nature, Kalamanje, Linganamakki, Sagara-Shimoga, India \\ ${ }^{3}$ Department of P.G. Studies and Research in Botany, Vijaynagara Sri Krishdaevaraya \\ University, Ballary, India \\ *Corresponding author
}

\section{A B S T R A C T}

Keywords

Folklore People, Medicinal Plants, Sedum Taluk.

Article Info

Accepted:

16 October 2016

Available Online:

10 November 2016
Present work was carried out among the folklore people of Sedam Taluk region during the year 2014-15. Ethno-botanical uses of 33 medicinal plants belonging to 28 families were documented for various human ailments. The major families are Euphorbiacea, Aslepidaceae and Apocyanceae (2 species each) and most were herbs (30 sp.) and leaves contributed mainly to the plant part used for medicine preparation ( 24 ailments) followed by seed, roots and fruits. This report includes ailments; botanical name of the plant, local name, family of the plant, part used and details about usage related human health problems.

\section{Introduction}

Medicinal plants have a promising future because there are about half million plants around the world (Dilfuza et al., 2015; Bassam and Rasool, 2012). The most of them their medical activities have not investigate yet and their medical activities could be decisive in the treatment of present or future studies (Rasool, 2012; Chopra and Nayar, 1956). Herbal medicines are the synthesis of therapeutic experiences of generations of practicing physicians of indigenous systems of medicine for over hundreds of years. They are known to be oldest health care products that have been used by mankind all over the world in the form of folklore medicines or traditional medicines or ethnic medicines. The therapeutic use of herbal medicines is gaining considerable momentum in the world during the past decade (Dubey et al., 2004). The World Health Organization (WHO) estimates that herbal medicine is still the mainstay of about $75-80 \%$ of the world population, mainly in the developing 
countries for primary health care because of better cultural acceptability, better compatibility with the human body and lesser side-effects.

Climate change and global warming are the warming calls and very well acknowledged threats today worldwide and almost all the species of world biodiversity are affected by the same (Abdul, 2013). In recent times, these anthropogenic activities have already knocked the door of existing biological resources worldwide exerting a pressure apparently or none apparently. On the living style and resources practices by the people of Ayurveda conceivably the old pioneer of all medicinal system of world uses various resources like plants animal and minerals for alleviation of illness climate change may not merely biggest threat to the local medicinal plant practitioners, but it is well acknowledged that, the existing used by the practitioners of this system will be highly affected in future due to increasing threat from anthropogenic pressure and climate change. Medicinal plant conservation strategies need to be understood and planned for based on an understanding of indigenous knowledge and practices (Parashurama and Kavyashree, 2015). Habitat loss is one of the threats to medicinal plants, change in environment also contribute to the change in ecological niche. Over exploitation is another cause but change in status of medicinal plants within its environment and community affects its availability in the particular area. As mentioned earlier, change in climate whether it is environmental or man made changes greatly influences on the community structure of the medicinal plants (Shivakumar and Parashurama, 2015; Raju and Parashurama, 2015). Least concentration has been given in this direction in research fields. In Karnataka, many workers reported on tribal groups and rural districts to document the ethno- medicinal value of plants used by them (Harsh et al., 2002; Parinitha et al., 2005; Prakasha and Krishnappa, 2006). Studies have been carried out in the Chikmagalur and Chitradurga (Shivanna et al., 2008; Hiremath et al., 2010; Ramachandra et al., 2012; Shivakumar and Parashurama, 2015; Raju and Parashurama, 2015; Vinay et al., 2015). Comprehensive detailed information on ethno-botanical knowledge in Karnataka that are lacking to certain areas (Parashurama and Kavyashree, 2015; Bhandari et al., 1995; Parinitha et al., 2004, 2005; Somashekar Achar and Shivanna, 2006). Present study focus towards the availability and uses of medicinal plants in Sedum Taluk along with the changes in medicinal plants community level in the view of medicinal practitioners.

\section{Materials and Methods}

The study area, Sedam Taluk is located between North latitude $17.183^{\circ}$ and between East longitude $77.283^{0}$ in Northeast parts of Karnataka. The town is spread over an area of 5.5 square kilometers. The mean temperature ranges between $32-43^{\circ} \mathrm{C}$ and $07-24^{\circ} \mathrm{C}$ in summer and winter season respectively. Sedam Taluk shares borders with three Taluk in the Kalaburgi district Chitapur Taluk to the west, chincholi Taluk to the north and Yadagiri district to the south. It also borders Tandur Taluk of the Rangareddy district of the Andhrapradesh and Kodangal Taluk of the Mahebubnagar district in Andhrapradesh to the rest. As of 2015 census Sedam had population of 31529. Males constitute $51 \%$ of the population and Females 49\%. Sedam has an average literacy rate of $58 \%$ lower than the national average of $59.5 \%$ male literacy is $66 \%, 16 \%$ of the population is under 6 years of age.

During the study, phytoethnomedicine information of Sedam Taluk among the 
people is collected through interviews followed by the questionnaire (Parashurma and Kavyashree, 2015). The peoples of all the age groups were interviewed and their knowledge about the medicinal plants was documented. The people are first enquired whether they give the herbal medicine to common ailments like cold, cough, dysentery fever, stomachache, headache etc., were collected. The information regarding the medicinal plants, preparation of medicine, dosage etc., were collected. The people were also informed about the herbal plants availability during present days and olden days to compare the ecological status. After each interview the interviewed persons were requested to show the medicinal plants whatever they informed. The medicinal plants were collected and are photographed also. During the visit it is noticed that some peoples who practiced the medicine are not ready to disclose the name of the plant. According to their beliefs, if the name of the plant is disclosed means plant loses its healing property. In such cases they were convinced by the significance of the study and the importance of the documentation of traditional knowledge, then only they interacted and told what they known about the herbal medicine. Medicinal plants which are collected during the study are identified with the help of floras (Gamble et al., 1935) and other medicinal plants reference books.

\section{Results and Discussion}

To investigate the ethno botanical uses of Sedum Taluk and their ecological status, 15 local residents from different villages were interviewed and data was collected. The present study reveals that in the Sedam Taluk local residents used 33 species of plants belongs to 23 genera and 28 families. The ethnobotnical survey conducted in India has brought to light several promising medicinal plants which are being used by the ethnic peoples and by traditional rural people in their health care of centuries. This has also led to the discovery of some unique and indigenous system of medicine practiced in India since time immemorial.

Table.1 List of plants used by folklore people in SedumTaluk for human healthcare purposes

\begin{tabular}{|c|c|c|c|c|c|}
\hline $\begin{array}{l}\text { Sl. } \\
\text { no }\end{array}$ & Scientific name/Family & $\begin{array}{l}\text { Common } \\
\text { name }\end{array}$ & $\begin{array}{l}\text { Part } \\
\text { used }\end{array}$ & Mode of use & Disease \\
\hline 01 & $\begin{array}{l}\text { Datura metel L. } \\
\text { Solanaceae }\end{array}$ & Belidatri & Leaf & $\begin{array}{l}\text { Leaf extract was } \\
\text { employing over a } \\
\text { region of swelling }\end{array}$ & Bulge \\
\hline 02 & $\begin{array}{l}\text { Cassia sophere L. } \\
\text { Caesalpinaceae }\end{array}$ & Chagachi & Seed & $\begin{array}{l}\text { Powdered seed mix } \\
\text { with coconut oil use } \\
\text { for itching part of the } \\
\text { boy }\end{array}$ & Allergy \\
\hline 03 & $\begin{array}{l}\text { Daemia extense (Jacq.) } \\
\text { R,Br.ex. Schutt. } \\
\text { Asclepiadace }\end{array}$ & Kurataga & Leaf & $\begin{array}{l}\text { Extracted leaf juice } \\
\text { taken orally }\end{array}$ & $\begin{array}{l}\text { Tummy } \\
\text { ache }\end{array}$ \\
\hline 04 & $\begin{array}{l}\text { Calotropis gigantea } \mathrm{L} \text {. } \\
\text { Apocynaceae }\end{array}$ & Yakke gida & Leaf bud & $\begin{array}{l}\text { Bud, clustered apple } \\
\text { bud, paan leaf mix } \\
\text { with lime and } \\
\text { employing for } \\
\text { treatment of lump }\end{array}$ & lump \\
\hline 05 & $\begin{array}{l}\text { Jatropha gossypiifolia L. } \\
\text { Euphorbiacae }\end{array}$ & Avalgida & Leaf bud & $\begin{array}{l}\text { Crush the leaf and } \\
\text { taken orally with }\end{array}$ & Jaundice \\
\hline
\end{tabular}




\begin{tabular}{|c|c|c|c|c|c|}
\hline & & & & sheep milk & \\
\hline 06 & $\begin{array}{l}\text { Tagetes erecta } L . \\
\text { Asteraceae }\end{array}$ & Chendhuvu & Leaf & $\begin{array}{l}\text { Wash the ear and } \\
\text { apply Tagetes erecta } \\
\text { leaf extracted in pus } \\
\text { formed region of ear }\end{array}$ & $\begin{array}{l}\text { Ear } \\
\text { seepage }\end{array}$ \\
\hline 07 & $\begin{array}{l}\text { Annona squamosa } \mathrm{L} \text {. } \\
\text { Annonaceae }\end{array}$ & Seethapal & Seed & $\begin{array}{l}\text { Crush the seed in } \\
\text { water and apply over } \\
\text { the swelling part }\end{array}$ & Bulge \\
\hline 08 & $\begin{array}{l}\text { Mangifera indica } \mathrm{L} \text {. } \\
\text { Anacardiacea }\end{array}$ & Mavu & Seed & $\begin{array}{l}\text { Mango seed is burn } \\
\text { it and extracted paste } \\
\text { is applied }\end{array}$ & Swelling \\
\hline 09 & $\begin{array}{l}\text { Cassia occidentale } \mathrm{L} . \\
\text { Leguminose }\end{array}$ & $\begin{array}{l}\text { Doddaehaga } \\
\text { chi }\end{array}$ & leaf & $\begin{array}{l}\text { Extracted leaf } \\
\text { applied over burnt } \\
\text { place after the drying } \\
\text { of scorched part }\end{array}$ & Scorched \\
\hline 10 & $\begin{array}{l}\text { Phyllanthus amarus } \\
\text { Schumacher } \\
\text { Euphorbiacae }\end{array}$ & Hajarigida & Leaf & $\begin{array}{l}\text { Extracted leaf juice } \\
\text { taken orally }\end{array}$ & $\begin{array}{l}\text { Blood } \\
\text { pressure }\end{array}$ \\
\hline 11 & $\begin{array}{l}\text { Aristolochia indica } \mathrm{L} . \\
\text { Aristolochiacae }\end{array}$ & $\begin{array}{l}\text { Ganigyan } \\
\text { gida }\end{array}$ & Leaf & $\begin{array}{l}\text { Leaf extracted juice } \\
\text { is mixed with pepper } \\
\text { taken orally }\end{array}$ & Pits \\
\hline 12 & $\begin{array}{l}\text { Piper nigrum } \mathrm{L} . \\
\text { Piperacae }\end{array}$ & Kalumenasu & Seed & $\begin{array}{l}\text { Powder mixed with } \\
\text { jiggery and applied } \\
\text { over bite portion }\end{array}$ & $\begin{array}{l}\text { Scorpion } \\
\text { bite }\end{array}$ \\
\hline 13 & $\begin{array}{l}\text { Achyranthes aspera L. } \\
\text { Amaranthaceae }\end{array}$ & Uttrarani & Leaf & $\begin{array}{l}\text { Leaf powder is } \\
\text { mixed with jiggery } \\
\text { and applied over } \\
\text { corn part }\end{array}$ & corns \\
\hline 14 & $\begin{array}{l}\text { Moringa olefera } \mathrm{L} \text {. } \\
\text { Moringaceae }\end{array}$ & Nuggegida & Leaf & $\begin{array}{l}\text { Leaves are boiled in } \\
\text { salt water and taken } \\
\text { orally }\end{array}$ & $\begin{array}{l}\text { Cholera, } \\
\text { Cough }\end{array}$ \\
\hline 15 & $\begin{array}{l}\text { Annona squamosa L. } \\
\text { Annonaceae }\end{array}$ & Sithapala & Seed & $\begin{array}{l}\text { Powdered seed is } \\
\text { mixed with coconut } \\
\text { oil apply over the } \\
\text { wounds }\end{array}$ & Gash \\
\hline 16 & $\begin{array}{l}\text { Acacia aspera } \mathrm{L} . \\
\text { Mimosaceae }\end{array}$ & Huchababli & Seed & $\begin{array}{l}\text { Powdered reed } \\
\text { mixed with honey } \\
\text { taken orally }\end{array}$ & $\begin{array}{l}\text { Scorpion } \\
\text { bite }\end{array}$ \\
\hline 17 & $\begin{array}{l}\text { Acacia anegadensis } \\
\text { Britton } \\
\text { Leguminosae }\end{array}$ & $\begin{array}{l}\text { Mullu } \\
\text { mutalu }\end{array}$ & Leaf & $\begin{array}{l}\text { Take a jiggery with } \\
\text { Acacia anegadnesis } \\
\text { leaf orally }\end{array}$ & Dog bite \\
\hline 18 & $\begin{array}{l}\text { Cucumis sativus } \mathrm{L} . \\
\text { Cucurbitaceae }\end{array}$ & $\begin{array}{l}\text { Soutekai } \\
\text { balli }\end{array}$ & Leaves & $\begin{array}{l}\begin{array}{l}\text { Leaves are taken } \\
\text { orally }\end{array} \\
\end{array}$ & $\begin{array}{l}\text { Scorpion } \\
\text { bite }\end{array}$ \\
\hline 19 & $\begin{array}{l}\text { Opuntia humifusa (Raf.) } \\
\text { Raf. } \\
\text { Cactaceae }\end{array}$ & Papaskalli & Fruit & Fruit taken orally & Headache \\
\hline 20 & $\begin{array}{l}\text { Annona squamosa L. } \\
\text { Annonaceae }\end{array}$ & Sitapala & $\begin{array}{l}\text { Unripe } \\
\text { fruit }\end{array}$ & $\begin{array}{l}\text { Tablets are prepared } \\
\text { using powder of } \\
\text { unripe fruit and } \\
\text { horsegram powder, }\end{array}$ & $\begin{array}{l}\text { Intestinal } \\
\text { infection }\end{array}$ \\
\hline
\end{tabular}




\begin{tabular}{|c|c|c|c|c|c|}
\hline & & & & $\begin{array}{l}\text { daily } \\
\text { a tablet is taken for } 7 \\
\text { successive days and } \\
\text { on the } 7^{\text {th }} \text { day, a } \\
\text { teaspoonful castor } \\
\text { oil is given orally to } \\
\text { expel worms from } \\
\text { the intestine. Seed } \\
\text { powder paste is } \\
\text { applied on head and } \\
\text { washed to remove } \\
\text { lice }\end{array}$ & \\
\hline 21 & $\begin{array}{l}\text { Argemone mexicana L. } \\
\text { Papavaraceae }\end{array}$ & Datturgida & Root & $\begin{array}{l}\text { Root powder is taken } \\
\text { as a antihelminthic. } \\
\text { Stem latex is applied } \\
\text { over affected skin, } \\
\text { blister and oral } \\
\text { ulcers }\end{array}$ & $\begin{array}{l}\text { Oral } \\
\text { ulcers }\end{array}$ \\
\hline 22 & $\begin{array}{l}\text { Asparagus racemosus } \\
\text { Willd. } \\
\text { Liliaceae }\end{array}$ & Shatavari & Root & $\begin{array}{l}\text { Shatavari and } \\
\text { Withania root } \\
\text { powder taken in the } \\
\text { morning enhance } \\
\text { fertility. Fresh root } \\
\text { extracts is taken as } \\
\text { diuretic }\end{array}$ & Infertility \\
\hline 23 & $\begin{array}{l}\text { Barleria prionitis L. } \\
\text { Acanthaceae }\end{array}$ & Mullugoranti & Root & $\begin{array}{l}\text { Root decoction is } \\
\text { used as mouthwash } \\
\text { to relieve tooth ache } \\
\text { and to prevent decay }\end{array}$ & $\begin{array}{l}\text { Tooth } \\
\text { decay }\end{array}$ \\
\hline 24. & $\begin{array}{l}\text { Boerhavia diffusa L. } \\
\text { Nyctaginaceae }\end{array}$ & kommegida & Root & $\begin{array}{l}\text { Root powder and } \\
\text { honey is orally taken }\end{array}$ & Infertility \\
\hline 25 & $\begin{array}{l}\text { Barleria prionites } \mathrm{L} . \\
\text { Acanthaceae }\end{array}$ & Mullugoranti & Leaf & $\begin{array}{l}\text { Fresh leaf paste is } \\
\text { applied on the } \\
\text { scabies }\end{array}$ & scabies \\
\hline 26 & $\begin{array}{ll}\text { Boerhavia } & \text { diffusa } \\
\text { L.nom.cons. } & \\
\text { Nyctaginaceae } & \\
\end{array}$ & kommegida & Leaf & $\begin{array}{l}\text { Leaf is pounded and } \\
\text { filtered, filtrate is } \\
\text { used as eye drop }\end{array}$ & $\begin{array}{l}\text { Eye } \\
\text { irritation }\end{array}$ \\
\hline 27 & $\begin{array}{l}\text { Datura metal L. } \\
\text { Solanaceae }\end{array}$ & Datturagida & Leaf & $\begin{array}{l}\text { Leaf and shade dried } \\
\text { flower is smoked to } \\
\text { treat asthma }\end{array}$ & Asthama \\
\hline 28 & $\begin{array}{l}\text { Daucus carota L. } \\
\text { Apiaceae }\end{array}$ & Gajjari & Root & $\begin{array}{l}\text { Carrot juice is given } \\
\text { daily to improve } \\
\text { digestion and good } \\
\text { eye sight }\end{array}$ & $\begin{array}{l}\text { digestion } \\
\text { and good } \\
\text { eye sight }\end{array}$ \\
\hline 29 & $\begin{array}{l}\text { Gymnosporia Montana } \\
\text { (Roth) Benth. } \\
\text { Celastracea }\end{array}$ & Tonasigia & Leaf & $\begin{array}{l}\text { Tender leaf extract } \\
\text { along with curd is } \\
\text { taken orally }\end{array}$ & Dysentry \\
\hline 30. & $\begin{array}{l}\text { Mentha arvensis } \mathrm{L} \text {. } \\
\text { Lamiaceae }\end{array}$ & Pudina & Leaf & $\begin{array}{l}\text { Leaf juice along with } \\
\text { equal part of lime } \\
\text { juice taken orally }\end{array}$ & vomiting \\
\hline
\end{tabular}




\begin{tabular}{|c|c|c|c|c|c|}
\hline 31 & $\begin{array}{l}\text { Momordica cymbalaria } \\
\text { Hook.f } \\
\text { Cucurbitaceae }\end{array}$ & Karchikai & Root & $\begin{array}{l}\text { Root tuber grounded } \\
\text { into paste, with } \\
\text { pinch of pepper } \\
\text { powder taken in the } \\
\text { Morning (during) } \\
\text { early period of } \\
\text { pregnancy }\end{array}$ & $\begin{array}{l}\text { Abortic } \\
\text { agents }\end{array}$ \\
\hline 32 & $\begin{array}{ll}\text { Phyllanthus fraternus } \\
\text { G.L.webster } & \\
\text { Euphorbiacae } & \end{array}$ & Nelanelli & Leaf & 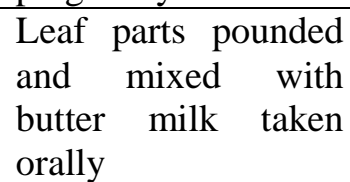 & Jandice \\
\hline 33 & $\begin{array}{l}\text { Tylophora indica (Burn.f) } \\
\text { merill } \\
\text { Asclepiaaceae }\end{array}$ & $\begin{array}{l}\text { Adumuttada } \\
\text { gida }\end{array}$ & Leaf & $\begin{array}{l}\text { Fresh leaves eaten } \\
\text { daily }\end{array}$ & Asthma \\
\hline 34 & $\begin{array}{l}\text { Vinca rosea (basionym) } \\
\text { Apocynaceae }\end{array}$ & Sadamallige & Leaf & $\begin{array}{l}\text { Dried leaves } \\
\text { powdered boiled in } \\
\text { water is taken orally }\end{array}$ & $\begin{array}{l}\text { Blood } \\
\text { Pressure }\end{array}$ \\
\hline 35 & $\begin{array}{ll}\text { Atylosia sericea } \\
\text { Benth.x.Baker } \\
\text { Fabaceae }\end{array}$ & Aditogari & Seed & $\begin{array}{l}\text { Powdered seed is } \\
\text { mixed with ghee } \\
\text { taken orally }\end{array}$ & Mentality \\
\hline 36 & $\begin{array}{l}\text { Enicostemma } \\
\text { hyssopifolium (Wild.)ver } \\
\text { Gentianaceae }\end{array}$ & Chirayath & Leaf & $\begin{array}{l}\text { Extracted leaf is } \\
\text { taken orally }\end{array}$ & Malaria \\
\hline 37 & $\begin{array}{l}\text { Emex spinosa (L.) campd. } \\
\text { Polygonaceae }\end{array}$ & Neggigida & Leaf & $\begin{array}{l}\text { Extracted leaf juice } \\
\text { is applied over the } \\
\text { corns }\end{array}$ & corns \\
\hline 38 & $\begin{array}{l}\text { Coriandrum sativum } \mathrm{L} \text {. } \\
\text { Apiaceae }\end{array}$ & Kottambari & Leaf & $\begin{array}{l}\text { Extracted leaf Juice } \\
\text { is applied over the } \\
\text { burnt part }\end{array}$ & smolder \\
\hline 39 & $\begin{array}{l}\text { Gouania tiliaefolia } \mathrm{L} . \\
\text { Rhamnaceae }\end{array}$ & Singari gouri & Seed & $\begin{array}{l}\text { Powdered seed is } \\
\text { mixed with coconut } \\
\text { oil applied on pus } \\
\text { formed region of pus } \\
\text { formed in the car }\end{array}$ & $\begin{array}{l}\text { Ear } \\
\text { seepage }\end{array}$ \\
\hline 40. & $\begin{array}{l}\text { Ficus hispida } \text { c.f } \\
\text { Moraceae }\end{array}$ & Nela hatti & $\begin{array}{l}\text { Leaf/ } \\
\text { Seed }\end{array}$ & $\begin{array}{l}\text { Fresh leaves are } \\
\text { boiled in tea and } \\
\text { taken orally }\end{array}$ & $\begin{array}{l}\text { Constipati } \\
\text { on }\end{array}$ \\
\hline
\end{tabular}

Majority of plants species are herbs followed by trees. The leaves exhibiting main contribution towards treatment of 24 ailments followed by seed (08), Root (04) and fruit (02). The folk and hakims of sedam Taluk people use certain plants to treat specific diseases like Daemia extensa for Tummy ache, Jatropha for jaundice, Cucumis sativus for scorpion bite and for ear seepage, Aristolochia indica for pits, Pltyllanthus amarus for blood pressure,
Acacia anegadenis for dog bite, Opuntia humifusa for head ache, Gymnosporia montana for Dysentery, Emex spinosa for corns, Ficus hispida for constipation. The Annona squamosa recorded as for more than one ailment like gash, Intestinal infection and Bulge. The resident people when enquired about the ecological status of the medicinal plants based on their availability in the study area, they opined that many medicinal plants were available in olden 
days but their availability is scanty now at least for few plants. The reason behind this is the loss of habitat and much anthropogenic activity. And few respondents opined that the dust came from surrounding factories may be the reason behind the less availability of the medicinal plants.

Sedam Taluk folk people have an immense knowledge of phyto-ethno-medicine. The information regarding the medicinal plants, preparation for medicine, dosages etc. were collected by them. The plants were also collected for the herbarium from the interviewed person. The presence of such a these medicinal plant species and associated ethno-medicinal knowledge in the district compared to number of species reported for other regions in Karnataka (Harsha, 2002; Bhandary et al., 1995) indicates that the area has good diversity of medicinal plant species including a rich source of indigenous knowledge. The study also revealed that the old age persons have the lot of information but is goes on decrease towards the younger generation of the locality tends towards the Allopathic medicine and they neglect their own traditional system of medicine. Present work, an attempt has been made to document the traditional phytomedicine of this locality. If this work have not been done the knowledge of phytomedicine will gradually lost from the locality due to the modernization.

\section{Acknowledgement}

The authors sincerely acknowledge Dept. of Environmental Science, Gulbarga University, Kalaburgi, India for providing facilitates to carry over the work. The authors express their sincere thanks to the local herbal practitioners. Authors are highly obliged with the help rendered by Panchavati Research Academy for Nature, Kalamanji, Karnataka and valuable suggestions.

\section{References}

Abdul Ghani. 2013. A Review of Herbal medicines present status, future prospects.

Bassam Abdul Rasool Hassan. 2012. Medicinal plants (Importance and uses). Pharmaceutica Anaryticar ACTA.) MICS publishing Group.

Bhandary, M.J., Chandrashekar, K.R. and Kaveriappa, K.M. 1995. Medical ethnobotany of the Siddis of Uttara Kannada district, Karnataka, India. J. Ethnopharmacol., 47: 149-158.

Bharati, K., Avinash, B. and Sharma, B.L. 2009. Studies on ethnoveterinary uses of plant resource of Sikkim. The Indian Forester, 135(5): 691-696.

Chopra, L.C and Nayar, M.C. 1956. Glossary of Indian Medicinal Plants: Council of Scientific and Industrial Research, New Delhi.

Das, A. and Tag, H. 2006. Ethnomedical studies of Khamti tribe of Arunachal Pradesh. Indian J. traditional Knowledge, 5(3): 317-322.

Dilfuza Egamberdieva, Smriti Shrivastava, Ajit Varma. Plant growth promoting Rhizobacteria (PGPR) and medicinal plants, Spinger International Publishing, Swidzerland, 2005. pp 232-233.

Dubey, N.K., Kumar, R. and Tripati, P. 2004. Global promotion of herbal medicine: India's opportunity, Current Sci., 86(1): 37-41.

Gamble, J.S. 1995. Flora of the presidency of Madras. Mahendra Pal Singh Publications, Dehra Dun, 3 Volumes, Pages 2017.

Harsh, V.H., Hebbar, S.S., Hedge, G.R. and Shripati, V. 2002. Ethnomedical knowledge of plants used by Kunabi tribe, Karnataka, India. Fitoterapia, 73: 281-287. 
Hiremath, V.T., Vijaykumar, M.M.J. and Taranath T.C. 2010. Survey on Ethno medicinal Plants of Jogimatti Forest Chitradurga District, Karnataka, India. Environ. Int. J. Sci. Tech., 5: 223-233.

Parashurama, T.R. and Kavyashree, S. 2015. Ethno-Veterinary Health Care Plants in Jagalur Taluk of Davangere District, South India., Int. J. Sci. Res., (IJSR) 4(6): 2963-2971.

Parinitha, M., Harish, G.U., Vivek, N.C., Mahesh, T. and Shivanna, M.B. 2004. Ethno-botanical wealth of Bhadra Wildlife Sanctury in Karnataka. Indian J. Traditional knowledge, 3: 37-50.

Parinitha, M., Shrinivasa, B.S. and Shivanna, M.B. 2005. Medicinal plant wealth of local communities in some villages in Shimoga district of Karnataka, Indian J. Ethnopharmacol., 98 : 307-312

Parinitha, M., Srinivasa, B.S. and Shivanna, M.B. 2005. Medicinal plant wealth of local communities in some villages in Shimoga district of Karnataka, India. J. ethnopharmacol., 98: 307-312.

Prakasha, H.M. and Krishnappa, M. 2006. People's knowledge on medicinal plants in Sringeri taluk, Karnataka. Indian J. Traditional Knowledge, 5(3): 353-357.

Raju Kanti and Parashurama T.R. 2014. Ethno-Botanical Knowledge Health care in Hangal Taluk of Haveri district, Karnataka. Int. J. Innovative Pharmaceutical Sci. Res., 2(10):2344235.

Ramachandra Naik, M., Vaishnavi V, Preethi K, and Krishnamurthy, Y.L. 2012. Ethnoveterniary uses of Medicinal Plants among the Lambani Community in Chitradurga District, Karnataka, India. Asian Pacific J. Tropical Biomedicine., S470-S476.

Shivakumar, H.M. and T. R. Parashurama. 2014.

Phyto-Ethno-Medicinal Knowledge of Folklore People in Kappathgudda Region of Gadaga District, Karnataka, South India, Int. J. Sci. Res., (IJSR), 3(11):3080-3091.

Shivanna, M.B., Mangala, K.R. and Parinitha Mahishi. 2008. Ethnomedicinal knowledge of Lambani community in Chikmagalur district of Karnataka, India, J. Medicinal Aromatic Plant Sci.. 30: 105-108.

Somashekar Achar, K.G and M.B. Shivanna. 2006. Khare- vokkaligas as a potential source for phyto-ethnomedicinal knowledge in Karnataka. 9-10.

Vinay, M.B., Vasanthakumar, K. and Parashurama, T.R. 2015. EthnoMedico-Botanical Knowledge of Rural Folk in Anagodu Forest of Davangere District, South India. Int. J. Sci. Res., (IJSR), 4(4): 2589-2594.

\section{How to cite this article:}

Prakash Kariyajjanavar, Sandesh Yargol, K.G. Somashekar Achar and T.R. Parashurama. 2016. Traditional Healthcare Knowledge of Sedum Taluk, Kalaburgi, Karnataka, South India. Int.J.Curr.Microbiol.App.Sci. 5(11): 321-328. doi: http://dx.doi.org/10.20546/ijcmas.2016.511.035 